DOI: 10.1515/rpp-2016-0011

Doctor of Pedagogical Sciences, Full Professor, ANATOLIY KUZMINSKY

Bohdan Khmelnytskyi Cherkasy National University, Ukraine Address: 81 Shevchenko Blvd, Cherkasy, 18031, Ukraine

E-mail: tetyanna@ukr.net

\title{
INTEGRATIVE APPROACHES OF NATIVE AND FOREIGN SCHOLARS TO PEDOLOGY IN THE CONTEXT OF VIEWS OF THE THIRD MILLENNIUM
}

\begin{abstract}
Problems of appearing and functioning of human study science, i.e. pedology, have been studied in the paper. Theoretical analysis of integrative approaches of native and foreign scholars to pedology in the context of views of the third millennium has been performed. Useful and positive achievements of this science as well as wrong ones determined by specific features of time and socio-political conditions, views on children upbringing have been singled out. It has been indicated that at the beginning of the $21^{\text {st }}$ century authoritarian, lacking humanism, scientistic-progressivistic educational paradigm is becoming history. At the same time child-centered, personal-developmental pedagogy is being increasingly included in the teaching practice. In addition, we can clearly trace contours of humanitarianexistential approaches to upbringing problems, which is why we should understand that there is no average child and that except heredity and environment much in the development of a small person depends on upbringing efforts of parents, pedagogues, state and society. Children should not adapt to the conditions since educational-upbringing system, curricula and methods of teaching must be adapted to a child, his/her capabilities, interests and specific features. A child's interests should be in the basis of the upbringing system. Any system of a child's upbringing, no matter how progressive and innovative it may be, will not fulfill its mission if it is not based on deep scientific pedology. Rather perspective we consider theoretical analysis of the development of the ideas on integral study of a child in Ukrainian pedology.

Key words: pedology, pedagogy, child, upbringing, formation, socialization, development, integrative approaches.

\section{INTRODUCTION}

The subject of pedology is a human being in development. Pedologists studied the development of a human body and factors affecting it. P. P. Blonsky in his book "Pedology" defined pedology as a science of a child's age development in conditions of certain social and historical environment (Блонский, 1934).

\section{THE AIM OF THE STUDY}

The aim of this article is to examine the problem of the origin and functioning of pedology and to theoretically analyze integrative approaches of native and foreign scholars to the science in the context of views of the third millennium.

\section{THEORETICAL FRAMEWORK AND RESEARCH METHODS}

There are different views and approaches to solving the question - when and where pedology as a science originated and who is its founder. Thus, M. Rumyantsev considers that the study of children appeared in Germany and doctor D. Tideman, who in 1787 published his work "Monitoring the Development of Mental Abilities in Children", can be considered its founder. It is necessary to mention that there is no solid, crosscutting,
\end{abstract}


comprehensive child development theory up to this time. Some pedologists mainly studied problems of childhood psychology. Other experimenters and theorists on the study of a child examined physical aspects of the latter. One of the first researchers was a Belgian scientist A. Quetelet, who in 1835 made first systematic measurements and weighs of children to identify regularities of a child's growth.

D. Tideman and A. Quetelet were the first researchers of a child as a direct and certain subject of study. And if one looks at the problem in a broader perspective, many scientists namely, V. Bekhterev (Russia), A. Binet (France), P. Blonsky (Russia), J. A. Comenius (Czech Republic), S. Hall (USA), I. Korczak (Poland), E. Maiman (Germany), M. Montessori (Italy), O. Nechayev (Russia), Y.-H. Pestalozzi (Switzerland), I. Rozsolimo (Russia), J. J. Rousseau (France), E. Thorndike (USA) and other researchers studied various aspects, features, qualities and characteristics of a child from different angles and at different times.

Ukrainian scientist S. Honcharenko in his "Ukrainian Pedagogical Dictionary" considers an American psychologist S. Hall, who in 1899 in Chicago (USA) established the first pedological laboratory, to be the founder of pedology (Гончаренко, 1997).

Belarusian researcher Ye. Rapatsevych argues that the author of the term "pedology" is S. Hall's student O. Krisment (Рапацевич, 2005).

Russian scientist-pedagogist K. Ushynsky in 1867 in his book "Man as a Subject of Education" expressed an opinion in unison with pedological views: "If pedagogy wants to bring up a person in all dimensions, it should also first of all come to know the person in all respects" (Ушинський, 1952). And more: "An educator should strive to come to know a person in reality, with all weaknesses and in all greatness, with all commonplace, small needs and with all great spiritual requirements. An educator should know a person in the family, in society, among people, among humanity and alone with his/her conscience; in any age, in all classes, in all situations, in joy and in sorrow, in humiliation and in greatness, in his/her prime and in disease, among unlimited hopes and on the deathbed, when the word of human consolation is already powerless. He/she must know motives of dirtiest and best actions, history of birth of evil and great ideas, the history of development of any passion and any character. Only then he/she will be able to draw in the very human nature means of upbringing influence - and these means are huge" (Ушинський, 1952). The K. Ushynsky's thoughts that are mentioned above as well as all his theoretical and practical activities give objective grounds to consider the great scientist and pedagogue to be one of the first and the most prominent founders and developers of pedological theory.

A special sweep acquired pedological researches in the 1920s. In 1928-1929 the first (and the last) congress of pedologists was held that lasted nine days. At the congress the decision was made to create pedological society of the USSR and a special magazine "Pedology".

During our study such methods as analysis, synthesis, analogy, comparison and individualization have been used.

\section{RESULTS}

Unfortunately to the detriment of the children upbringing for subjective, totally illogical reasons pedology by resolution of the Central Committee of the CPSU (b) on July 4, 1936 "About Pedological Distortions in the System Commissariat" was completely destroyed as a reactionary, bourgeois pseudoscience. All scientific researches in this field were suspended and banned, and scientists were persecuted. And though since those unfortunate times nearly eight decades passed and conditions and views on researches in the field of human study sciences changed, in modern scientific sources, in pedagogical and 
psychological literature of Ukraine unjustifiably little attention is paid to the problems, which once pedology took care of. Now we can very rarely meet even the term "pedology" itself, not to mention the recovery of serious complex researches of such important in the life of society phenomenon. Obviously, to some extent echoes of massacre of the 1930s are reflected, which is not conducive to the desire of scientists to engage pedological problems. But we wish they would, since true and conscientious pedologists set a task to create foundations of the science of a child in a holistic and systematic form and they managed to do much useful in that area.

Of particular importance and topicality are the problems of dependence of quality of education on the capacity and health of students in our time. Modern way of life is defined by internal instability, inconsistency and loss of usual orientations and search for relevant for time philosophical and axiological orientations. Insecurity in tomorrow, anxiety for their own future and for their loved ones, economic, political, environmental, existential crisis cause global stress and neuroticism of population, increasing the number of psychosomatic diseases. Especially this unfavorable social environment affects the younger generation. The conflict between the focus of modern education on the intensification of the learning process and psychosomatic capabilities of students becomes more escalating.

Realizing that a child as a subject of scientific research is a rather complex natural phenomenon, outstanding domestic pedagogues, practitioners, innovators show scientific interest to various aspects of studying specific features and reularities of mind and body of a child being in dynamics of its development. To this problem many works by A. Bogush, A. Makarenko, O. Savchenko, O. Sukhomlynska, V. Sukhomlynsky, O. Zakharenko, I. Zyazyun et al. are dedicated.

It is necessary to take into account that in fact not all in the history of pedology is scientifically substantiated, objective and progressive. There were also much pondered, formal, artificially adapted to ideological and political demands of that time. But having crushed and banned pedology as a science, the rulers of that time alongside with that slowed for a long period, which inertially lasted until now, researches of such an important problem, having made an irreparable damage to growing, formation, development, socialization of a child and education of a person in general.

In our opinion, it would be very useful to go back to those truly scientific achievements of pedology, which were worked out by scientists of this field in the $19^{\text {th }}$ century and in 1936 of the $20^{\text {th }}$ century. One of the key figures in the field of studying the development a child is M. Basov (1892-1931). The graduate of Nature-and-History Department of Pedagogical Faculty of St. Petersburg Neuropsychiatric Institute professor M. Basov in different years worked at the Institute for the Study of Brain and Psychic Activity organized by V. Bekhterev, Neuropsychiatric Academy, State Institute of Scientific Pedagogy (Leningrad), O. Hertsen State Pedagogical Institute (Leningrad). Among many works of the scientist his monograph "The General Principles of Pedology" is of special value for a modern teacher. Under the term "pedology" M. Basov understood "scientific synthesis of all that makes the essential results of some scientific disciplines which study a person that develops each from its side" (Басов, 1931). The abovementioned work is a collection of research materials on the age anatomy and physiology of a child as well as child psychology.

And now there is a tense debate around the problem of the role of heredity as a factor of human development. Supporters of the so-called biological approach consider genetically inherent by nature properties to be the determining factor in human development. Scientists of sociological direction insist on determination of the social environment, which is dominant in the development of an individual. M. Basov thoroughly and carefully came 
to studying the abovementioned problem starting to study the problem of human development since the connection of a mother's egg cell and a father's spermatozoon. He states that modern science (the beginning of the $20^{\text {th }}$ century is meant $-\mathrm{A}$. K.) leaves no doubt that the parents' gametes which give rise to a new organism, and they are carriers of various and numerous parental characteristics, transmitted in several generations under the laws of heredity. In these limits the material basis of heredity can be considered to be firmly established" (Басов, 1931).

M. Basov's views on the role of environment in formation of personality are instructive and useful for current researchers of problems of human development. It is a matter of common knowledge that when a researcher is biasedly, prejudicedly convinced in validity and authenticity of certain information, he acts in such a way that it should get actual evidence (Pygmalion effect, or it is also called Rosenthal effect). Biologists are sure that a person's fate entirely lies in heredity, and all the rest is just minor addition to genetic pre-definiteness. But life's realities evidently convince that environmental influence is powerful and overwhelming factor of life and development of all flesh and, first of all, a person. M. Basov states that a social factor permeates through material nature that surrounds a person, and in the same way all human nature in its most profound manifestations in this or that way reflects social environment that surrounds it (Басов, 1931).

A scholar uses eccentric and sometimes unexpected approaches in the study of the problem of influence of surrounding reality on human development in childhood. So, he studies the connection of environment and child mortality, environment and physical development of children, environment and child delinquency, environment and development of childrens' personalities.

Not rejecting the role of heredity in indicators of infant mortality, the scientist convincingly proves that this indicator is in direct connection with specific features of this or that environment, that high percentage of infant mortality is bitter fate of certain segments of population. Not diminishing the role of heredity, the researcher comes to conclusion that under the same external conditions first perish those children who have worse heredity. Given by the scientist data about child mortality (during the first year of life) in European countries in 1901-1905 evidently illustrate the determinative influence of environmental conditions. The lowest rate among twenty European countries is recorded in Norway (7.5 per 100 births) and the highest one - in Russia (26.3). Another convincing example of influence of environment, living conditions is analysis of infant mortality in Sweden for 150 years, from 1750 to 1900 . For 150 years, the coefficient of infant mortality in different age groups declined steadily. This fact is explained by constantly increasing socio-economic and cultural level of life of the country, that is by positive changes in the social environment.

Although M. Basov in those years tried to present results of his researches from class positions, based on Marxist theory, and it must be taken into account in their consideration, though the main trends, regularities and conclusions basically meet the requirements of objectivity of the study. The scientist convincingly proves in many examples that infant mortality rate depends on the social status of the family, on the size of income of its members. Besides, the quality of maternal care also has certain influence on infant mortality. The more a mother works outside the family, the less able she is to pay attention to care and development of a child, the more likely a child is to leave this world. An important role in development and preservation of life and health of a child plays the level of culture of a mother or both parents. Infant mortality is also connected with living conditions of a family. 
What is particularly important for the preservation of life and health of children in modern Ukraine is taking into account the regularity that during the war simultaneously with perishing of parents in the war their children also perish at a rear deprived of those sources of life they had in peacetime. This is certified by many facts of different wars of different times (Басов, 1931).

What are negative trends of pedological researches reflected in? First of all, they are reflected in formal, eclectic, often mechanistic approach to studying the essence of a child. P. Blonsky clearly and brightly said about that: "We must tell the truth: and now often pedology courses are actually vinaigrette of various branches of knowledge, a simple set of data from various sciences of everything that concerns a child. But is such vinaigrette a special independent science? Of course, it is not" (Руфин, Блонский, 1928).

Theoretical ideas of pedology did not impose with practice of training and upbringing. Specialists who were not familiar with pedagogical activity often conducted pedological researches. A. Makarenko criticized pedologists, who for a long time only studied his pupils but not implemented results of the study in a particular upbringing work.

Pedologists studied psychological, biological, anatomical, physiological, sociological specific features of the development of a child in the mechanical connection between them. In approaches to the study of personality of a child fatalistic grounds were a priori laid. A child's fate was closely connected with biological and social factors of influence, with defining role of heredity and environment.

In studying the specific features of a child's development the main method was testing, in which all parameters of a child's intelligence level, abilities, talents, opportunities were defined. But reflexologists I. Aryamov, A. Dernova-Yarmolenko, Yu. Frolov considered a child to be a mechanism, a machine that reacts to the influential actions of the environment.

Most pedologists of the early $20^{\text {th }}$ century were firmly convinced that the relationship between somatic and mental development is absolutely reliable and there is no doubt in it. To ground this idea, they relied on famous scientists' research results which from the standpoint of the present time cause serious doubts and, in our opinion, are not at all correct. For example, a famous French pedologist A. Binet, matching the size of a child's head with a child's mental development, gives such results (Table 1) (Калашникова, 1929).

Table 1

\begin{tabular}{|c|c|c|c|}
\hline & $\begin{array}{c}\text { Mental development } \\
\text { above average }\end{array}$ & $\begin{array}{c}\text { Normal mental } \\
\text { development }\end{array}$ & $\begin{array}{c}\text { Insufficient mental } \\
\text { development }\end{array}$ \\
\hline $\begin{array}{c}\text { Development } \\
\text { of a head above average }\end{array}$ & $50 \%$ & $30 \%$ & $20 \%$ \\
\hline Normal development of a head & $25 \%$ & $50 \%$ & $25 \%$ \\
\hline $\begin{array}{c}\text { Insufficient development } \\
\text { of a head (below average) }\end{array}$ & $25 \%$ & $58 \%$ & $40 \%$ \\
\hline
\end{tabular}

The same conclusion is made by an Italian scholar M. Montessori. The Pedagogical Encyclopedia (1929) published in Moscow publishing house "Rabotnik Prosveshcheniya" (Educator) in approving context gives such results of A. Binet's research with students from Paris and M. Montessori's - from Rome (Table 2) (Калашникова, 1929).

What positive and useful ideas did pedological science make in the theory and practice of a person's teaching, upbringing, care, formation and development? 
Table 2

\begin{tabular}{|c|c|c|c|c|c|c|}
\hline \multirow[b]{2}{*}{$\begin{array}{c}\text { Head } \\
\text { measurements }\end{array}$} & \multicolumn{3}{|c|}{ Binet's numerical data } & \multicolumn{3}{|c|}{ Montessori's numerical data } \\
\hline & \begin{tabular}{|c|} 
Pupils are \\
selected among \\
the most \\
advanced
\end{tabular} & $\begin{array}{l}\text { Backward } \\
\text { pupils }\end{array}$ & Difference & $\begin{array}{c}\text { Pupils are } \\
\text { selected among } \\
\text { the most } \\
\text { advanced }\end{array}$ & $\begin{array}{l}\text { Backward } \\
\text { pupils }\end{array}$ & Difference \\
\hline $\begin{array}{l}\text { Maximum } \\
\text { circumference } \\
\text { of a head }\end{array}$ & 540 & 530 & +10 & 527 & 513 & +9 \\
\hline $\begin{array}{l}\text { Length } \\
\text { of a head }\end{array}$ & 181 & 177 & +4 & 180 & 177 & +3 \\
\hline $\begin{array}{l}\text { Width } \\
\text { of a head }\end{array}$ & 150,4 & 146,2 & $+4,2$ & 143 & 140 & +3 \\
\hline $\begin{array}{l}\text { Height } \\
\text { of a head }\end{array}$ & 123,3 & 124 & $-0,7$ & 130 & 127 & +3 \\
\hline $\begin{array}{l}\text { Maximum } \\
\text { diameter } \\
\text { of a forehead }\end{array}$ & 104 & 102 & +2 & 99 & 98 & +1 \\
\hline $\begin{array}{l}\text { Height } \\
\text { of a forehead }\end{array}$ & 46 & 45,5 & $+0,5$ & 57 & 56 & +1 \\
\hline $\begin{array}{l}\text { Distance } \\
\text { from a nose } \\
\text { to a chin }\end{array}$ & 62 & 64,6 & $-2,4$ & 55 & 56 & -1 \\
\hline
\end{tabular}

First of all, pedology tried to give basics of science about a child in the broadest, all-embracing aspect, in a holistic, systemic and systematized form. Pedological research embraces the very essence of a child in a completely versatile way, not paying attention to any separate aspects. M. Basov expressed the subject of pedology in the most concentrated form: "And what is in this case left for pedology? I can answer this question only in such a way: a child is a whole left for it, in other words, pedology is a scientific synthesis of all that is an essential result of separate scientific disciplines which study a child each from its special aspect" (Басов, 1931). In these words of the prominent pedologist already in the first third of the last century the synergetic approach to the study of the most complicated and the greatest nature phenomenon - a phenomenon of a person was laid.

\section{CONCLUSIONS}

So, at the beginning of the $21^{\text {st }}$ century authoritarian, lacking humanism, scientisticprogressivistic educational paradigm is becoming history. At the same time child-centered, personal-developmental pedagogy is being increasingly included in the teaching practice. In addition, we can clearly trace contours of humanitarian-existential approaches to upbringing problems, which is why we should understand that there is no average child and that except heredity and environment much in the development of a small person depends on upbringing efforts of parents, pedagogues, state and society. Children should not adapt to the conditions since educational-upbringing system, curricula and methods of teaching must be adapted to a child, his/her capabilities, interests and specific features. A child's interests should be in the basis of the upbringing system. Any system of a child's upbringing, no matter how progressive and innovative it may be, will not fulfill its mission if it is not based on deep scientific pedology. Rather perspective we consider theoretical analysis of the development of the ideas on integral study of a child in Ukrainian pedology. 


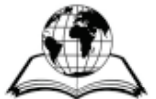

\section{REFERENCES}

1. Басов, М. Я. (1931). Общие основы педологии [General Basics of Pedology]. Москва-Ленинград : Гос. изд.-во, 802 р. (in Russian).

2. Блонский, П. П. (1934). Педология [Pedology]. М. : Гос. учеб.-пед. изд-во, 356 p. (in Russian).

3. Гончаренко, С. (1997). Украӥнський педагогічний словник [Ukrainian Pedagogical Dictionary]. Київ : Либідь, 376 р. (in Ukranian).

4. Калашникова, А. (1929). Педагогическая энциклопедия [Pedagogical Encyclopedia]. Москва : «Работник просвещения», 884 p. (in Russian).

5. Рапацевич, Е. С. (2005). Педагогика: больщая современная энциклопедия [Pedagogy: Large Modern Encyclopedia]. Москва : «Соврем. слово», 720 p. (in Russian).

6. Румянцев, М. Ю. (1910). Педологія [Pedology]. СПб. : Вид. О. Богданової, 74 p. (in Ukranian).

7. Руфин, И. И. (1928). Блонский П. П. в его педагогических высказываниях [P. P. Blonsky in his Pedagogical Statements]. М. : «Работник просвещения», 116 p. (in Russian).

8. Ушинський, К. Д. (1952). Людина як предмет виховання (спроба педагогічної антропологіi) [A Person as a Subject of Upbringing (an Attempt of Pedagogical Upbringing)]. Київ : Державне учбово-педагогічне видавництво «Радянська школа», 126 р. (in Ukranian).

9. Фрадкин, Ф. А. (1991). Педология: мифы и действительность [Pedology: Myths and Reality]. Москва : Знание, 80 p. (in Russian). 